\title{
WSPOMNIENIE
}

KLIO. Czasopismo poświęcone dziejom Polski i powszechnym

PL ISSN 1643-8191, t. 20 (1) 2012, s. 315-318

\section{Profesor Marian Biskup (19 XII 1922-16 IV 2012)}

$\mathrm{O}$

dszedł od nas uczony o europejskim autorytecie wynikającym nie tylko z imponującego dorobku naukowego, ale też ze swych zdolności organizacyjnych. Pochodził z rodziny wywodzącej się z Pałuk (północnowschodniej Wielkopolski). Jego rodzice Zofia i Mieczysław tuż przed pierwszą wojną światową przenieśli się do Inowrocławia, gdzie otworzyli piekarnię. Zainteresowania humanistyczne pojawiły się u Profesora już podczas nauki w znanym tamtejszym Gimnazjum im. Jana Kasprowicza. Podczas drugiej wojny światowej znalazł zatrudnienie jako „pomocnik biurowy” w inowrocławskiej spółdzielni rolniczo-handlowej prowadzonej oczywiście przez Niemców. Po wojennej przerwie kontynuował naukę w swojej szkole, chcąc szybko nadrobić opóźnienia, przeszedł jednak do liceum dla dorosłych i tam w lutym 1946 r. zdał maturę. Już wcześniej zdecydował o podjęciu studiów historycznych na nowo utworzonym Uniwersytecie Mikołaja Kopernika w Toruniu i od listopada 1945 r. uczestniczył w niektórych zajęciach jako wolny słuchacz. 25 II 1946 r. stał się formalnym studentem UMK'1. W Toruniu trafił na sprzyjającą wówczas atmosferę naukową. Znaleźli się tu znani historycy z uniwersytetów lwowskiego i wileńskiego. Mistrzem młodego adepta historii stał się jednak prof. Karol Górski z Poznania, który już przed wojną podjął badania nad stosunkami polsko-krzyżackimi w średniowieczu. To on wprowadził swego ucznia w tajniki warsztatu historycznego. Pod jego też kierunkiem Marian Biskup napisał w 1949 r. pracę magisterską poświęconą postaci Jana Cegenberga, współtwórcy Związku Pruskiego w pierwszej połowie XV w. (opublikowaną w „Zapiskach TNT”), a w następnym roku doktorską dotyczącą stosunku Gdańska do

1 Wspomnienia z lat inowroctawskich. Rozmowa z prof. dr. Marianem Biskupem o mieście dzieciństwa i mtodości (przeprowadzona przez Edmunda Mikołajczaka i Stanisława Roszaka), „Ziemia Kujawska”, t. 12: 1997, s. 5-27; M. Biskup, Inowroctawskie wspomnienia, „Ziemia Kujawska”, t. 19: 2006, s. 125-145. 
Kazimierza Jagiellończyka w okresie wojny trzynastoletniej. W czasach stalinowskich nie było jednak szans na uzyskanie etatu na UMK dla wychowanka tak „reakcyjnego" profesora, jak Karol Górski. Zresztą i samemu M. Biskupowi zarzucano, że jest zwolennikiem „burżuazyjnego idiografizmu”, gdyż zajmuje się biografiami wybitnych postaci, a nie walką mas ludowych ${ }^{2}$. Początkowo Marian Biskup był więc nauczycielem w toruńskich szkołach średnich (zaczął uczyć jeszcze w czasie studiów, w 1947 r. i kontynuował tę działalność do 1951 r.). Potem w latach 1951-1953 został zatrudniony w toruńskim oddziale, bardzo wówczas aktywnego Instytutu Zachodniego. Możliwość szerszej pracy badawczej uzyskał w 1954 r. w Instytucie Historii PAN w Zakładzie Historii Pomorza (w toruńskiej Pracowni Historii Pomorza Wschodniego). W tym też Zakładzie, którym przez dłuższy czas kierował, pozostawał aż do przejścia na emeryturę w końcu 1992 r. Jedynie w latach 1957-1972 prowadził również zajęcia dydaktyczne na kierunku historia na UMK.

Profesor Marian Biskup praktycznie bez przerwy intensywnie pracował nad dziejami ziem pomorskich, Kujaw, szeroko pojętej strefy bałtyckiej. Swoje badania koncentrował na epoce przejścia od średniowiecza do wczesnych czasów nowożytnych (XV-XVI w.). Zajmował się przyłączeniem Pomorza Nadwiślańskiego (Prus Królewskich) do Polski w połowie XV w. (praca na ten temat przyniosła mu stopień docenta w 1958 r.), wojnami polsko-krzyżackimi, zwłaszcza wojną trzynastoletnią z lat 1454-1466 (poświęcił jej obszerną monografię) i konfliktem zbrojnym między Polską a Zakonem z lat 1519-1521, oraz genezą sekularyzacji Prus Krzyżackich i hołdu pruskiego z 1525 r. (tej tematyki dotyczy kilka Jego książek), wewnętrznymi strukturami zakonu krzyżackiego i jego inflanckiej gałęzi, polityką zagraniczną państwa polskiego w dobie Jagiellonów, geografią historyczną, wreszcie dziejami miast. Wystarczy tu wskazać na atlas Prusy Królewskie $w$ drugiej połowie XVI wieku, napisaną wspólnie z Gerardem Labudą obszerną syntezę Dzieje Zakonu Krzyżackiego w Prusach: gospodarka, społeczeństwo, państwo, ideologia, czy na znaczący udział Profesora w redagowaniu wielotomowej Historii Pomorza i Historii dyplomacji polskiej. Szczególne miejsce w Jego badaniach zajmowała postać Mikołaja Kopernika jako kanonika warmińskiego reprezentującego stany pruskie i działającego w ich imieniu. Prof. Marian Biskup opublikował i redagował około 850 prac naukowych. O nowatorstwie Jego metod naukowych w badaniach nad późnym średniowieczem decydowało odejście od opierania się na dokumentach, kronikach, rocznikach i innych źródłach opisowych. Podobnie jak to robią historycy czasów nowożytnych, sięgał do źródeł masowych: korespondencji prywatnej i dyplomatycznej, spisów podatkowych, rachunków. Tak intensywna działalność na-

2 H. Samsonowicz, Marian Biskup i „Zapiski Historyczne”, „Zapiski Historyczne”, t. 72: 2007, z. 2-3, s. 79. 
ukowa przyniosła mu w 1961 r. tytuł prof. nadzwyczajnego, w dziesięć lat później awans na prof. zwyczajnego, w 1991 r. wybór na członka korespondenta, a następnie na członka rzeczywistego PAN. Od r. 1991 był też członkiem odrodzonej PAU. Otrzymał też doktoraty honoris causa Uniwersytetu Adama Mickiewicza w Poznaniu i Uniwersytetu Gdańskiego.

Znaczną część dorobku naukowego prof. Mariana Biskupa stanowią edycje źródeł historycznych, przede wszystkim kontynuowanie, wydawanej przedtem przez Karola Górskiego, wielotomowej serii „Akta Stanów Prus Królewskich”, zawierającej protokoły posiedzeń władz stanowych, ich korespondencję z królami polskimi, dostojnikami państwowymi i zakonem krzyżackim, a także listy wielkich miast pruskich. Od tomu szóstego współwydawcą była żona Profesora doc. dr hab. Irena Janosz-Biskupowa. Po zakończeniu tej edycji zainicjował wydawanie Protokołów sejmiku generalnego Prus Królewskich (od 1526 r.), instytucji, która przejęła funkcje wcześniejszych władz stanowych (Rady Pruskiej). Publikował też materiały dotyczące działalności publicznej Mikołaja Kopernika, m.in. Regesta Copernicana i osobiście spisane przez słynnego astronoma Lokacje łanów opuszczonych na Warmii po wojnach krzyżackich. U schyłku życia wraz z żoną, przy współpracy historyków niemieckich, podjął się edycji wizytacji przeprowadzonych w średniowieczu na terenach należących do zakonu krzyżackiego (także w jego baliwatach niemieckich i włoskich).

Wśród polskich historyków jest kilka, może kilkanaście osób, których dorobek naukowy pod względem liczbowym i merytorycznym można byłoby porównywać z osiągnięciami Profesora Biskupa. Na ich tle wyróżniał się On jednak swoimi talentami organizacyjnymi. Już w 1958 r., ku pewnemu zaskoczeniu starszej profesury, objął redakcję toruńskiego czasopisma naukowego „Zapiski TNT”, przekształcając je w „Zapiski Historyczne”, nowoczesny periodyk zajmujący się dziejami Pomorza i Europy Północnej. Kierował redakcją aż do 2003 r. Jednocześnie jako długoletni sekretarz generalny (w latach 1965-1983), a potem prezes Towarzystwa Naukowego w Toruniu (do 2004 r.), inspirował i organizował badania naukowe, dbał o materialne i finansowe zaplecze TNT. Jego działalność w Polskim Towarzystwie Historycznym przyniosła mu wybór na prezesa PTH (przez dwie kadencje w latach 1973-1978).

Ważna była działalność Profesora na polu międzynarodowym i aktywny udział w niezliczonych sesjach i kongresach, a także współudział w organizacji ważnych wystaw historycznych. Szczególne znaczenie miało nawiązanie przez Niego (w czasach gdy po obu stronach występowała głęboka nieufność i liczne urazy) bli-

3 Por. M. Biskup, Toruńskie „Zapiski Historyczne” w latach 1958-2003. Kierunki działań, „Zapiski Historyczne”, t. 72: 2007, z. 2-3, s. 15-43; H. Samsonowicz, op. cit., s. 77-79. 
skich kontaktów z historykami niemieckimi zajmującymi się problematyką państwa zakonnego w Prusach. Okazało się, że historiografia polska ma do zaoferowania nowoczesny warsztat badawczy i spore osiągnięcia edytorskie. Odegrał też istotną rolę w komisji podręcznikowej polsko-niemieckiej, a potem w 1985 r. w powołaniu w Wiedniu Międzynarodowej Komisji Historycznej do spraw Badań nad zakonem krzyżackim, której został wiceprzewodniczącym ${ }^{4}$.

Profesor potrafił (i lubił) kierować pracami zbiorowymi. To z Jego inicjatywy powstały wielotomowe syntezy dziejów Bydgoszczy, Torunia, rodzinnego Inowrocławia, czy skromniejsze książki poświęcone historii Chełmna, Koronowa i Szubina. Istotną zaletą była umiejętność uzyskiwania funduszy na tego typu wydawnictwa (niezależnie od przemian ustrojowych w kraju). Oprócz „Zapisek Historycznych” redagował także inne regionalne czasopisma historyczne, m.in. „Ziemię Kujawską" i „Rocznik Elbląski”, zainicjował też wydawanie „Rocznika Grudziądzkiego” i „Prac Komisji Historii Bydgoskiego Towarzystwa Naukowego”. Wywierał znaczący wpływ nie tylko na toruńskie środowisko historyczne, liczono się z Jego opiniami w kraju, doceniano Jego dorobek także zagranicą. To właśnie skłoniło znakomitego poznańskiego historyka Gerarda Labudę do określenia Go jako - „człowieka instytucję" ${ }^{5}$. Ta działalność na polu lokalnym przyniosła Profesorowi obywatelstwo honorowe trzech miast: Torunia, rodzinnego Inowrocławia i Elbląga.

Był człowiekiem miłym, nawet ciepłym w codziennych kontaktach, ale jednocześnie stanowczym i wymagającym. Przysłowiowa była jego pracowitość i systematyczność. Potrafił jednocześnie pracować nad kilkoma monografiami i edycjami źródłowymi, mając jeszcze czas na czytanie powieści i krótkie spacery.

Jerzy Dygdata

${ }^{4}$ Szerzej o początkach i efektach współpracy naukowej polsko niemieckiej zainicjowanej przez Mariana Biskupa zob.: U. Arnold, Drogi Kolego Marianie!, „Zapiski Historyczne”, t. 72: 2007, z. 2-3, s. 45-58 i K. Zernack, Możemy powiedzieć - byliśmy przy tym, tamże, s. 81-88.

5 G. Labuda, Naukowy i społeczno-obywatelski trud Mariana Biskupa, „Zapiski Historyczne", t. 72: 2007, z. 2-3, s. 59-79. 